\title{
Impacts of Climate Change, Variability and Adaptation Strategies on Agriculture in Two Agricultural Communites of Enugu State, Nigeria
}

\author{
Agu N. N. \\ Department of Quantity Survey, Nnamdie Azikiwe University, Awka, Anambra
}

\begin{abstract}
A study was carried in two agricultural zones of Enugu State, Nigeria The overall objective of this study was to understand local communities' perceptions on climate and variability issues and establish its impacts and adaptation strategies within agricultural sector. Both primary and secondary data were used. Primary data were obtained using different Participatory Research Approaches (PRA) including, focus group discussions and household questionnaires. In each community, a sample size of 10\% of all households was interviewed. Findings showed that local people perceived changes in rainfall pattern and temperature increase. The changes have affected their crops in a number of ways resulting in reduced productivity. Empirical analysis of annual rainfall revealed the decreasing rainfall trend from 1980 to 2012 whereas mean maximum and minimum temperature showed increasing trend within the year. The study concluded that, the wealth of knowledge on coping and adaptation that farmer has should form a foundation for designing agricultural innovation systems to deal with impacts of climate change and variability.
\end{abstract}

Keywords: Climate Change Impacts, Adaptation Strategies, Agricultural Communities, Enugu State

\section{Introduction}

In rural communities of Nigeria, agriculture plays a very important role in providing food and income for the majority of the population. In Enugu State the agricultural sector is a key to economic development (Ibe, 2008). Over $85 \%$ of the population rural communities of Enugu state depend on subsistence agriculture which is almost entirely rain fed. It accounts for an average of $50 \%$ of Gross Net Product in the area. Climate change and variability is rapidly emerging as one of the most serious global problems affecting many sectors in the world and is considered to be one of the most serious threats to sustainable development with adverse impact on agriculture, environment, human health, food security, economic activities, natural resources and physical infrastructure (IPCC, 2007). Nigeria is one of the most vulnerable regions to climate change in the Africa. According NEST (2004). Nigeria is particularly vulnerable to the impacts of climate change because of factors such as widespread poverty, recurrent droughts and floods, inequitable land distribution and over dependence on rainfed agriculture. Daniel and Eddey (2004) reported that rural communities in Nigeria are already among the most food insecure in the world and Climate change will result in food insecurity. Ekpo and Nzegbule (2012) reported that agriculture has been identified to be the second most vulnerable sectorto the impacts of climate change. A study on vulnerability and adaptation to climate change impacts on other sectors in Nigeria indicated that forestry, water, coastal resources, livestock and human health are also likely to be vulnerable to climate change (NEST 2008). These sectors are closely linked to agriculture and therefore effects of Climate change on such sectors will further negatively affect both crops and livestock production systems. The impacts of climate and variability are manifested by floods, droughts, erratic rains and extreme events. URT (2005) revealed that famine resulting from either floods or drought has become increasingly common since the mid-1990s and is undermining food security. Climate change are likely to intensify flood and increase potential vulnerability of the communities to future climate change especially in the tropical regions, where crop production are critically important to food security and rural livelihoods. A number of studies conducted recently in coastal region of Nigeria have recognized that Climate change is happening and is coupled with significant impact on various natural resources including agriculture which is the main source of livelihood in rural areas (Agrawala et al., 2003). Various climaterelated impacts such as floods and droughts regularly have substantial effects on economic performance and livelihood of communities in rural areas that depend on rain-fed agriculture. A study by Ekpo (2012) on climate change and famine in coastal communities of Akwalbom State indicated that the presence of dry spells in critical periods for most crops contributed considerably to crop failure. Given the over-dependence on rain-fed agriculture by the majority of people living in rural areas, Climate change has been one of the major limiting factors in agriculture production thus resulting in food insecurity and low-income generation. The studies conducted by Rosenzweig et al. (2002) revealed that changes in rainfall patterns and amounts have led to loss of crops and reduced livestock production. Increasing impacts of Climate change in particular drought and floods on agriculture have been associated with various adaptation and coping mechanisms (Gwambene, 2007). These are based mainly on indigenous knowledge which embodies a wide variety of skills developed outside the formal education system (UNFCCC, 2003). Such coping and adaptation mechanisms include increased exploitation of non- timber forest products and increased wetland cultivation (Kangalawe et al., 2005; Yanda et al., 2007), this indicates clearly how rural people adapt to climate change. Indigenous knowledge arises out ofcontinuous experimentation, innovation and adaptation, blending many knowledge systems to solve local problems (UNFCCC, 2003).Climate change is a global phenomenon while adaptation is largely site-specific. It is very important to clearly understand what 


\section{International Journal of Science and Research (IJSR) \\ ISSN (Online): 2319-7064 \\ Index Copernicus Value (2013): 6.14 | Impact Factor (2015): 6.391}

is happening at community level, because farmers are the most climate-vulnerable group.

This study explored indigenous knowledge on perceptions, vulnerability, adaptations strategies, coupled with scientific analysis of the prevailing climatic changes in the areas of study and established enhanced adaptations of the agricultural systems.

\section{Research Methodology}

\section{Description of the study area}

The study was carried out in two agricultural communities of Enugu State, Nigeria. The communities were Adani and Opanda, these communities are known for the production rice, vegetables and other food crops. Enugu State is located between Latitudes $4^{\mathrm{O}} 30^{\mathrm{I}}$ and $7^{\circ} 00^{\mathrm{I}} \mathrm{N}$ and Longitudes $5^{\circ} 30^{\mathrm{I}}$ and $9^{\circ} 30^{\mathrm{I}} \mathrm{E}$. The area has a land area of $75,488 \mathrm{~km}^{2}$.

The state has a total population of $31,371,941$ (NPC, 2006) and an average population density of 416 persons per square kilometer. Madu (2005) observed that population pressure is the most important problem of rural development in the region. The effects of population pressure in the area have been recognized in a broad spectrum of livelihood activities such as intensive agriculture, engagement in non-farm activities and migration.

The communities lies entirely within the tropical zone and has warm, humid climate. The average temperatures are uniformly high throughout the year with a slight variation between $26^{\circ} \mathrm{C}$ and $27^{\circ} \mathrm{C}$. Reports of low temperature of $16^{\circ} \mathrm{C}$ during the local dry Harmattan period and high soil temperature as of $45^{\circ} \mathrm{C}$ have been reported during the peak of the dry season. The mean relative humidity ranged between $70 \%$ and 90\% (Enugu State Government Gazette 1992). Enugu state is characterized by two seasons, namely the wet season, which last from March to November with the peaks of rainfall in July and August while the dry season last from November to March. The rainfall pattern is usually bimodal. The amount of rainfall varies between $1500 \mathrm{~mm}$ and $3000 \mathrm{~mm}$ (Enugu State Agricultural Development Programme (ENADEP, 2006). This encourages farming activities in the area. The major occupation of the people in rural communities of Enugu State includes faming and trading.

The vegetation in the Enugu state is predominantly the disturbed lowland rainforest formation (secondary forest or bush fallow). The original complex structure and species richness of the zones have been converted. Most disturbances are through human interference for which there is evidence in the form of farms, roads, human settlements and cutting of fuel wood. Also land use patterns in Southeast zone of Nigeria are virtually unregulated, promoting exploitation of both timber and non-timber forest produce to an extent that endangers the very existence of the vegetation (Dike, 2010).

The soil types found in Enugu state are associated with one another in an intricate manner, but very similar (Ano, 1994). They are deep, heavy loamy soil to sandy loam with surface layers that are prone to erosion. These soils are generally not only acidic, but very low in basic cationic nutrients like
Calcium, Magnesium and Potassium, except in the swamp areas where the soils are fairly rich in Potassium

\section{Data collection and processing}

Both primary and secondary data were collected in order to address the objectives of this study. Primary data were collected using multiple approaches including both quantitative and qualitative PRA methods were used to collect primary data from the study area. The methods used included key informant interviews, focus group discussion and structured questionnaire with a total number of 50 participants per community. Also, historical mapping of different climate related events over the past years that could be remembered were used. Secondary data included published research papers and relevant reports, rainfall and temperature data kept at Meteorological department, internet search and other relevant sources. The approaches used are quite similar to those used by Yanda et al. (2007). For household interviews, a stratified random sampling procedure based on their major economic activity were used. According to Kothari (2004), stratified sampling involves dividing the population into homogeneous groups containing subjects with similar characteristics. Qualitative data from various sources were examined and presented in different forms. Descriptive statistics were used to give frequencies and then cross-tabulation was undertaken. Multiple response questions were analyzed so as to give frequencies and percentages. Temperature and rainfall data from meteorological stations were analyzed using Microsoft Office Excel 2003 to present pattern and trends of rainfall and temperature in the form of graphs.

\section{Results and Discussion}

\section{Major economic activities in study areas}

Table 1 showedthat farming is the major economic activity in the studied communities of Enugu State. About (72.5\%) of the respondents in Adani and (65.9\%) in Opanda agreed that their major economic activities in the area is farming. Although livestock is the second major economic activity in Adani (35.3\%) and Opanda(25.0\%), all livestock keepers are also farmers and none of the respondents was keeping livestock alone. Petty traders ranked as the third economic activity. However the trading business activity appeared to be of less importance to Opanda(14.7\%) as compared to Adani $(20.3 \%)$. The higher percentage values observed in petty trading business in Adani farming community is due to the difference in the levels of development and urbanization. This implies that villagers in Adani stand a better chance of coping with the impacts of Climate change because they can diversify economic activities more easily than villagers in Opanda community. From the result, it was observed that farming and livestock keeping is the main economic activities in both communities. Thus, this implies that climate change will have a far-reaching effect on the livelihoods of these communities. Other minor economic activities in the studied communities included selling of local non-timber forest products, which was observed in Opanda community and was mainly done by women. In addition, the respondents agreed that there has been an increase in the number of women involved in the production of charcoal and the collection and selling of firewood. Also in Opanda farming community, few people involved in bee 


\section{International Journal of Science and Research (IJSR) \\ ISSN (Online): 2319-7064 \\ Index Copernicus Value (2013): 6.14 | Impact Factor (2015): 6.391}

keeping. It was observed that most of these emerging activities are non-farm activities.

Table 1: Major Economic Activity in the studied communities in Enugu State

\begin{tabular}{|c|c|c|}
\hline Major Economic Activity & $\begin{array}{c}\text { Adani } \\
\text { community \% }\end{array}$ & $\begin{array}{c}\text { Opanda } \\
\text { community \% }\end{array}$ \\
\hline Farming & 72.5 & 65.9 \\
\hline Livestock keeping & 35.3 & 25.0 \\
\hline Non-timber forest products & 12.5 & 22.7 \\
\hline Petting trading & 20.3 & 14.7 \\
\hline Selling of firewood/charcoal & 15.0 & 35.4 \\
\hline
\end{tabular}

Table 2 presents the existing farming systems in Adani and Opanda farming communities of Enugu state, Nigeria. The farming system include crop farming (referring to production of crops alone), mixed farming (referring to crop farming and livestock keeping), shifting cultivation and agroforestry. The high percentage of responses recorded in mono farming in the two communities showed that farmers are vulnerable to climate change. This shows that any outbreak of diseases in the farm will affect the whole crops and this will result in total loss of the crops. The percentage of the respondents in agroforestry system by the farmers in both communities indicate that their crops are vulnerable to climate change impact.

Table 2: Farming system in studied communities of Enugu State

\begin{tabular}{|c|c|c|}
\hline Farming system & Adani community & Opanda community \\
\hline Mono cropping & 50.5 & 45.0 \\
\hline Mixed cropping & 23.0 & 25.5 \\
\hline Shifting cultivation & 13.7 & 19.2 \\
\hline Agroforestry & 12.8 & 11.3 \\
\hline Total & 100.0 & 100.0 \\
\hline
\end{tabular}

Farmer's perceptions on long-term changes in temperature and rainfall in the studied communities Table 3 shows that $(63.8 \%)$ of the respondents in Opanda community and $(73.8 \%)$ in Adani community perceived that there was an increase in temperature over the last 15 years. It has been reported that over the last 15years during November to February the communities becomes extremely hot during the day and very cold during the night in both communities of Enugu State. The percentage respondents in Adani and Opanda farming communities were $(45.8 \%$ and $40.2 \%$ ) respectively who perceived changes in onset of rains and decrease in precipitation as well as increase in frequency of dry spelt during farming season. The majority of the respondents declared that rainfall onset has changed because they used to plant crops in February/March but nowadays they have to plant in May/June. Similar results were reported by NEST (2004) whereby a significant number of farmers in Nigeria believed that temperatures had increased and that precipitation had declined.
Table 3

\begin{tabular}{|c|c|c|}
\hline Changes in weather conditions & $\begin{array}{c}\text { Adani } \\
\text { community } \\
\%\end{array}$ & $\begin{array}{c}\text { Opanda } \\
\text { community } \\
\%\end{array}$ \\
\hline Decrease in precipitation & 33.2 & 25.8 \\
\hline Increase in temperature & 23.2 & 24.3 \\
\hline Changes in onset of rain & 17.3 & 21.2 \\
\hline Dry spelt during farming season & 14.0 & 15.6 \\
\hline Severe wind storm & 12.3 & 13.1 \\
\hline Total & 100.00 & 100.00 \\
\hline
\end{tabular}

\section{Trend of rainfall from 1980-2012}

Statistical record of rainfall in Enugu State Nigeria between 1980 to 2012 shows a decreasing trend with the highest volume of rainfall recorded in 1997 and 2006 that had ( $2315.1 \mathrm{~mm}$ and $2173.7 \mathrm{~mm}$ ), respectively. The lowest volume of rainfall was recorded in 1983 and 2004 (1215.4mm and 1226.3), respectively (Fig.1). Annual mean volume of rainfall in the studied areas was high throughout the period, this may be because the area is located in the tropical region of Nigeria which normally experience high amount of rainfall (Awosika, 2010). The mean and standard deviation of the rainfall data in Enugu State from 1980 to 2012 is shown in (Table 1). The trend coefficient is -1.0238 which shows that there is difference in variation in the amount of rainfall from year to year in the study area. The coefficient of correlation between rain fall and time has a value of 0.0259 implying that there is significant difference between the amount of rainfall and time. The correlation between rainfall and time is insignificant in the study area. This also implies that the area experienced heavy amount of rainfall from year to year, but the uncertainty in the rainfall pattern (timing and amount) at the studied area affect agricultural activities. Trobe (2000) predicted that climate change will pose serious threat to food security. This is because agriculture at the studied areas is highly dependent on rain; therefore changes in rainfall pattern have greatly affected agriculture in communities in Enugu state. The intermittent dry spell during farming season also contributes to the loss of farms produce at the studied areas. This is because farmers who plant after the first or second rain may run huge loss because the rains might be delayed beyond the usual period, and this will result by the crops being scotched by the heat of the sun causing huge economic loss. However, majority of the respondents opined that before this time farmers use to predict the time forwet season and they know precisely when to plant their crops. Presently, many farmers cannot predict the time for wet season. The increasingly severe crop failure and loss of yields due to false start of the rains, frequent intervening dry spells during the growing seasons, early cessation of rains thereby curtaining the growing season in the area. 


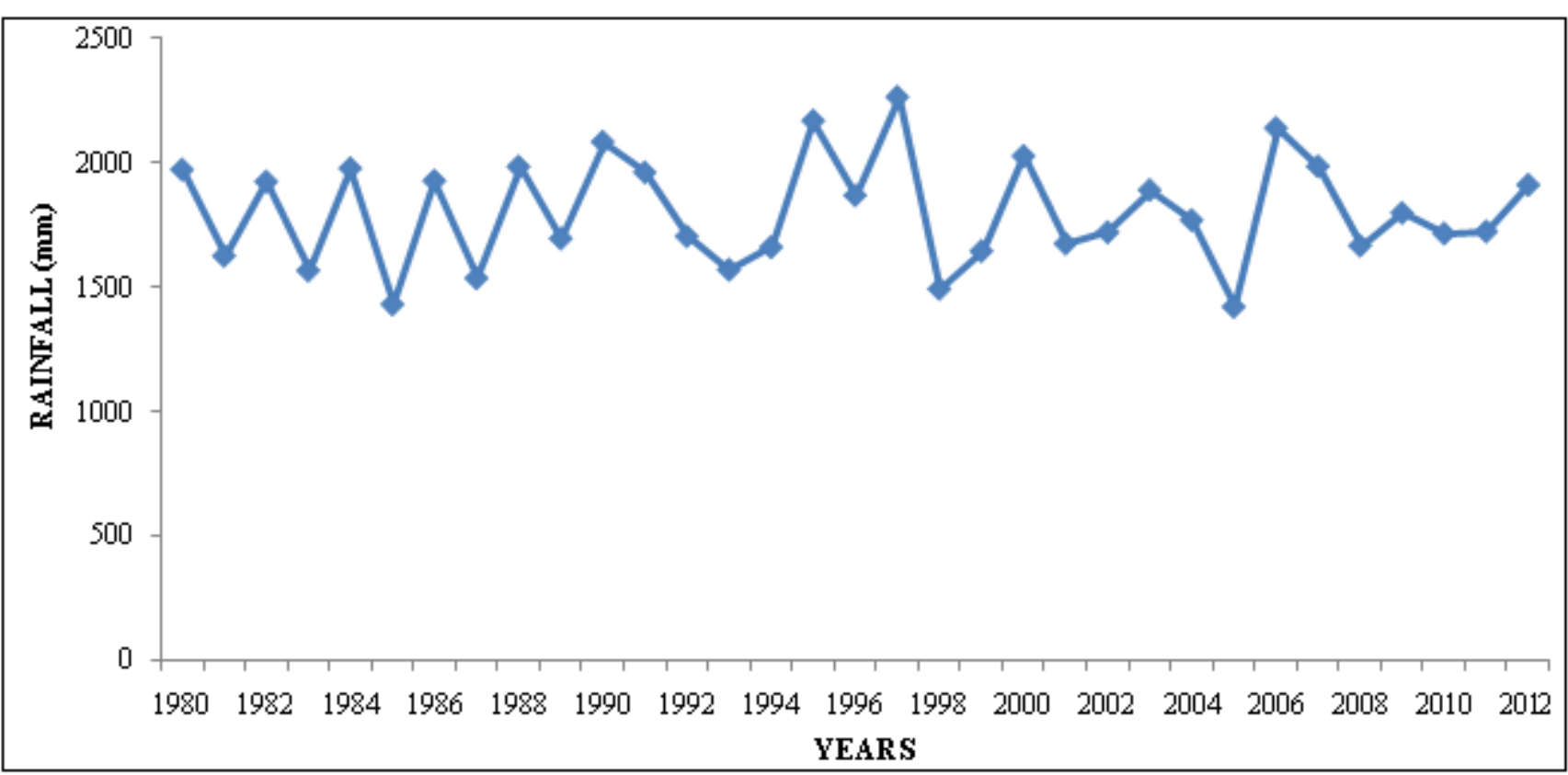

Figure 1: Trend of Rainfall in Enugu State from 1980-2012

Trend of temperature from 1980-2012 in Enugu State, Nigeria

Data on temperature from 1980 to 2012 shows an increasing trend with minimum temperature $\left(30.1^{\circ} \mathrm{C}\right)$ recorded in 1980 and maximum temperature $\left(32.4^{\circ} \mathrm{C}\right)$ recorded in 2010 (fig. $2)$. The mean value of temperature data and its standard deviation over the period in Enugu State are $30.3^{\circ} \mathrm{C}$ and $0.56^{\circ} \mathrm{C}$ respectively, implying that there is variability in temperature values from year to year. The trend coefficient is 0.2199 and is statistically significant. The coefficient of correlation of temperature and time is 0.8471 and is statistically significant implying that temperature has significant positive relationship with time. Normally, increase in temperature should have positive impacts on crop yield in the tropical areas because higher temperature enhances higher rates of bio-chemical reaction in plants. Therefore, the significance increased in temperatures may result in accelerated physiological development, leading to hastened maturation and decrease yield. Sombroek, (1996) reported that increased temperatures may accelerate the rate at which plants release carbon dioxide in the process of respiration, resulting in less than optimal conditions for net growth. When temperatures exceed the optimal for biological processes, crops often respond negatively with a steep drop in net growth and yield (Adejuwon, 2004). The most important climatic element determining the occurrence and localization pests and diseases appear to be temperature. In general, pests and disease vectors do better when the temperature is high under optimum water supply conditions (Adejuwon, 2004). Higher temperature is therefore likely to extend the range of distribution of certain pests and diseases of crops. The gains expected from longer growing seasons might not be realizable because of greater infestation by pests and diseases. Also high moisture levels recorded in the study areas might benefit pests and diseases rather than increase the yield of crops. This evidence suggests that longer growing seasons will enable insects such as grasshoppers to complete a greater number of reproductive cycles during the wet season. Also, the higher temperatures observed in the area may also allow larvae to multiply exceedingly in areas, thus causing greater infestation during the following cropping season. Rosenzweig and Hillel(1995), observed that altered wind patterns may change the spread of both wind-borne pests and of the bacteria and fungi that are the agents of crop disease. Croppest interactions may shift as the timing of development stages in both hosts and pests is altered; livestock diseases may be similarly affected (Adejuwon, 2004). 
International Journal of Science and Research (IJSR)

ISSN (Online): 2319-7064

Index Copernicus Value (2013): 6.14 | Impact Factor (2015): 6.391

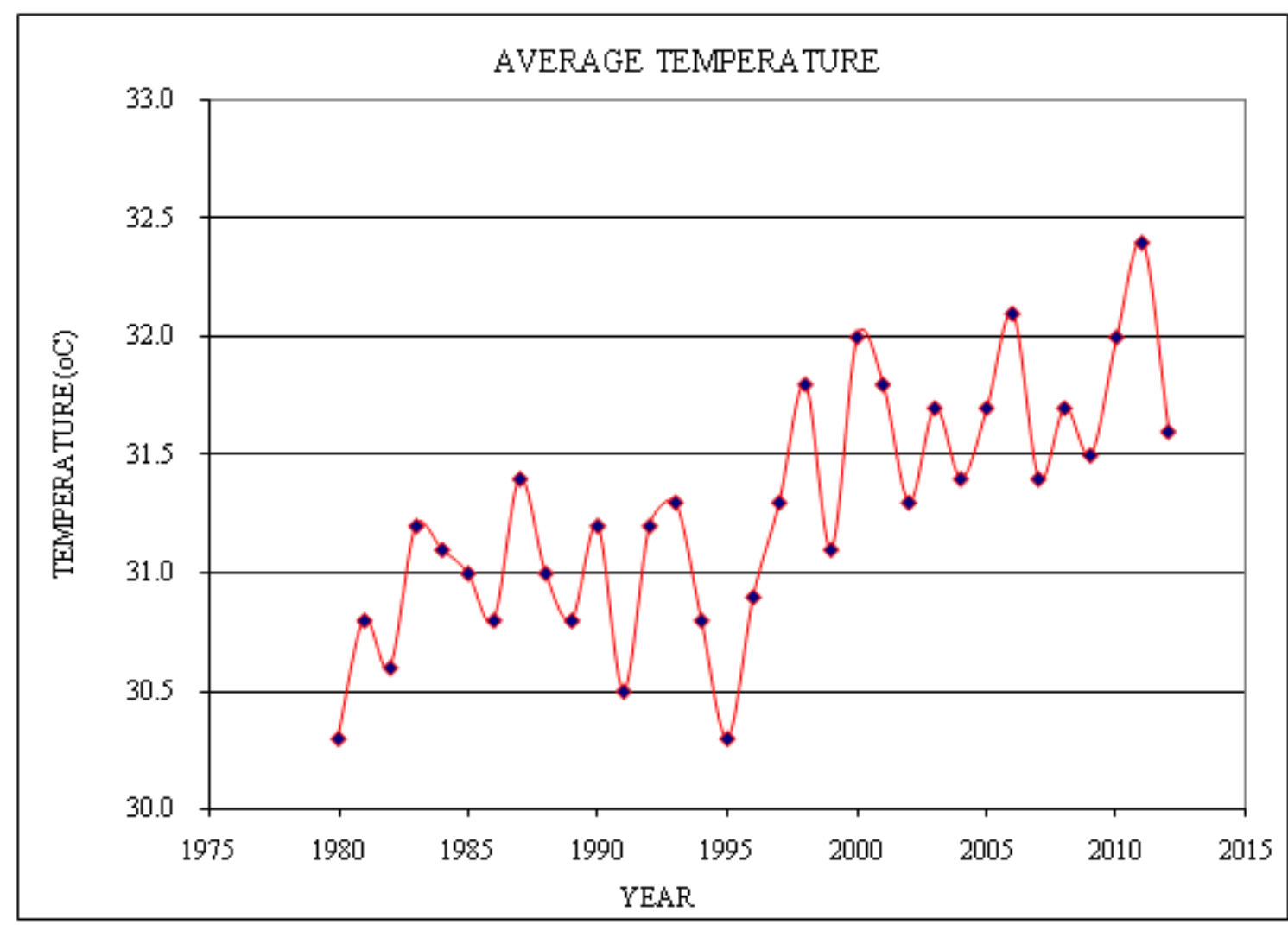

Figure 2: Trend of temperature in Enugu State from 1980- 2012

\section{Adaptation strategies to climate change impacts}

In response to the impacts associated with climate change, farming communities in Enugu State, Nigeriaare implementing different adaptation and coping measures as discussed below.

\section{Soil fertility improvement managementpractices}

Farmers in Adani and Opanda ensureproper timing of different farming activities.Preparation of land for planting starts early enough (mid of May) toavoid unnecessary competition for labour duringthe peak period which normally occurs soonafter the onset of rains. Some farmers bury cropresidues in the field so as to replenish the fertilityof the soil while others burn the residue toenhance quick release of nutrients. Similar findingswere reported by Majule, (1999) andSakala, (1998). Also burning of residue is done to ease cultivation and is a way of controllingcrop pests such as stalk borer. Adaptationto impacts of climate change in farming systems requires are silienceagainst both excess of water (due to high intensityrainfall) and lack of water (due to extended drought periods). The study by FAO (2007) concluded that a keyelement in response to both problems is to improve soilorganic matter. Soil organic matter stabilizes the soilstructure so that the soils absorb higher amounts of water without causing surface run-off, which could result in soilerosion and, or flooding downstream. Soil organic matter also improves the water absorption capacity of the soilduring an extended drought.

\section{Soils tillage practices}

Farmers classify soils locally by using color, natural fertility, depth and moisture-holding capacity. Two major dominant soil types are loamy and sandy soil. Loamy soil is darkish in color, sticky, fertile and holds moisture for a long time whereas sandy soil is not fertile and easily loses moisture.
Based on this categorization farmers select crops and determine planting dates to match the different soils. It was reported that farmer's plant maize and cassava crops on contour ridges, whereas vegetables and groundnuts were planted in flat bed. Farmers use contour ridges as a strategy to minimize soil erosion to encourage better root penetration and enhance moisture conservation. The findings are inline with a study by Mahoo et al. (2007) which reported that, farmers adopted tillage methods, agronomic practices and crop diversification approaches to maximize yield from available water. In this case, tillage tends to improve infiltration rates of water and thus reducing surface runoff associated with short but heavy rains which are usually common in study areas

\section{Staggered seed crop planting}

In both villages, most of the farmers use more than one plot for crop production. To avoid crop production risks due to rainfall variability and drought, staggered plating is very common to most farmers whereby crops are planted before rain onset (dry land) on uncultivated land. Others were planted immediately after rain, while still other plots were planted a few days after the first rains. Tilling the land commences in fields which were planted prior to cultivation on the third week after the onset of rain which also enables destroys early geminating weeds and reduces weeding. These were done purposely to distribute risk by ensuring that any rain was utilized to the maximum by the crop planted the in dry field (Liwenga, 2003).

\section{Mixed cropping}

Mixed cropping involves growing two or more crops in the same field. The system is commonly practiced in both villages where cereals (maize, sorghum), legumes (beans) and nuts (groundnuts) are grown together. From discussions 


\section{International Journal of Science and Research (IJSR) \\ ISSN (Online): 2319-7064 \\ Index Copernicus Value (2013): 6.14 | Impact Factor (2015): 6.391}

with farmers, it was noted that they have wide field knowledge on advantages of mixing crops with varying attributes in terms of maturity period (e.g. maize and beans), drought tolerance(maize and sorghum), input requirements (cereals and legumes)and end uses of the product (e.g. maize as food and sunflower for cash). The study revealed that farmers diversify crop types as a way of spreading risks on the farm (Adger et al., 2003). Crop diversification can serve as insurance against rainfall variability.

\section{Conclusions}

Crop production and livestock keeping are the major agricultural activities in the Adani and Opanda communities of Enugu State. The study has been able to establish that rainfall and temperature in study area has been decreasing and increasing respectively, negatively affecting the production and management of different crops. Different forms of changes on rainfall have been identified including shrinking of rain season by one month due to late on set of rainfall period by shifting from October to November ending in April instead of May. The analysis and perception of the local people indicated shift on the onset of long rains from October/November to December/January with shortening of rainfall period and increased frequency of drought. A combination of strategies to adapt, such as proper timing of agricultural operations, crop diversification, use of different crop varieties, changing planting dates, increased use of water and soil conservation techniques and diversifying from farm to non-farm activities does exists. However this study recommends that such measures needs to be strengthened.

\section{References}

[1] Adejuwon, S.A. (2004). Impacts of Climate Variability and Climate Change on Crop Yield in Nigeria. Lead Paper Presented at the Stakeholders. Workshop on Assessment of Impacts and Adaptation to Climate Change, Conference Center, Obafemi Awolowo University, Ille-Ife 20-21 September, 2004.

[2] Adger WN, Huq S, Brown K, Conway D, Hulme M (2003). Adaptation to climate change in the developing world. Progress Dev. Stud. 3: 179-

[3] Agrawala S, Moehder A, Hemp A, Van Aalst M, Hitz S, Smith J, MeenaH, Mwakifamba S, Hyera T, Mwaipopo O (2003). Dev. and ClimateChange in Tanzania: Focus on Mount Kilimanjaro. OECD, Paris.

[4] Ano, A. O. (1994). Trace metal Studies on Soils of the Nigeria Coastal Plain Sands Status of $\mathrm{Cu}, \mathrm{Zn}, \mathrm{Pb}, \mathrm{Fe}$, and Mn. Journal. of Soils and Crops, 4(1) 1-5

[5] Awosika, L. F. (1995). "Impacts of global climate change and sea level rise on coastal resources and energy development in Nigeria" In: Umolu, J.C. (ed). Global Climate Change: Impact on energy Development. DANTECH Nigeria Limited, Nigeria.

[6] Daniel S,and Eddey J (2004). Climate change and food security. IDSB. 35(3). Insti. of Dev. Studies, Univer. of Sussex, Brighton, UK.

[7] Dike, M. C. and Nwosu, R. G. (2011). Bush burning and its effect in Africa. A case study of Nigeria .Environmental Journal of Sc. 1(1): 10-20.

[8] Ekpo, F. E. and Nzegbule, E. C.(2012). .Climate change impact and adaptation opportunities on agricultural production in communities around Itu bridge-head in Itu LGA, Akwalbom State, Nigeria. International Journal of Environmental Sciences Volume 2, No 4, 2012

[9] Ekpo, F. E and Asuquo, M. E (2011). Agroforestry Practices as Adaptation Tools to Climate Changes Hazards in Itu Local Government Area of Akwalbom State. Global Journal of Human and Social Sciences. Vol.12 Issue 11,

[10]ENADEP (2006). Enugu State Agricultural Development Programme (ENADEP) Annual Report, 2006. Enugu.

[11]Enugu State Government Official Gazette (1992). Enugu State Official Gazette No. 25.

[12]Food and Agriculture Organization (FAO) (2007). Adaptation to climatechange in agric., forestry and fisheries: Perspective, framework andpriorities. Interdepartmental working group on climate change, Rome,Italy.

[13] Gwambene B (2007). Climate Change and Variability Adaptation Strategies and its Implications for LandResour. inRungwe District, Tanzania. M.Sc. Dissertation, IRA, Univer. of Dares Salaam, Dares Salaam, Tanzania.

[14] Ibe, S. U. (2008). Adaptation to climate change in agriculture, forestry and fisheries: Perspective framework and priorities, Food and Agriculture Organization of the United Nations Rome, Pp 149-155.

[15]IPCC (2007), ,Working Group II Fourth Assessment Report. ClimateChange: Climate Change Impacts, Adaptation and Vulnerability,http://www.ipcc.ch/SPM6avr07.pdf, retrieved on 5th July.

[16] Kangalawe RYM, Majule AE, Shishira EK (2005). An Analysis of Land Use Dynamics and Land Degradation Process In the Great Rift Valley, Central Tanzania: A Case of Iramba District. Book Published by OSSREA. ISBN 1904855628

[17] Kothari C (2004). Research Methodology; Methods and Technique Dharmesh Printers; New Delhi,

[18]Liwenga ET (2003). Food Insecurity and Coping Strategies in Semi-aridAreas: The Case of Mvumi in Central Tanzania. PhD Dissertation No.11. Stockholm Studies in Human Geography, Stockholm Univer,Stockholm, Sweden.

[19]Madu, I.A. (2005). "Population and settlement constraints to sustainable agricultural land use insoutheastern Nigeria," in Okoko, E. Adekunle, V.A.J and Adeduntan, S.A. (eds). Environmental Sustainability and Conservation in Nigeria.Environmental Conservation and Research Team, Federal University of Technology, Akure Nigeria pp. 163-171.

[20] Mahoo HF, Mkoga ZJ, Kasele SS, Igbadun HE, Hatibu N, Rao KPC,Lankaford B (2007). Productivity of water in agric.: Farmerse perceptionsand practices. Colombo, Sri Lanka: Int. Water Manage. Insti. (Comprehensive Assessment of Water Management in Agric. DiscussionPaper 5) ISBN 978-92-9090-679-7.

[21] Majule AE (1999). The Effects of Organic Residues and Elemental SulphurAdditions to Soils of Southern Tanzania. PhD Thesis, ReadingUniver. Reading, United Kingdom.

[22] Nigerian Environmental Study / Action Team (NEST), Nigeria / Global Change Strategies International 
(GCSI), Canada (2004) Executive Summary of Five Multi-Sector Surveys on Nigeria"s Vulnerability and Adaptation to Climate Change. Ibadan.

[23]Nigerian Environmental Study/Action Team, (2008) "Facts on Climate Change in Nigeria No. 4: Repercussions for Agriculture, Food Security, Land Degradation, Forestry and Biodiversity" Abuja:

[24]NPC (2006). Population Census of Enugu State. In; Census 2007. National Summary. National populationCommission (NPC), Abuja, Nigeria.

[25] Rosenweig, C. and Hillel, D. (1995).Potential Impact of Climate Change on Agriculture and Food Supply. Consequences: The Nature and Implications of Environmental Change, Vol. 1, No. 2, summer, 1995.

[26] Sakala MG (1998). The Effects of Incorporating Plant Residues on SoilAcidity in the Management of Tropical Soils. PhD Thesis, ReadingUniver., UK.

[27] Sombroek, W.G.(1996). The Climate Change Agriculture Conundrum; Global Climate Change and Agricultural Production.Direct and Indirect Effects. FAO Corporate Document Repository, USA, Pp128134

[28]Trobe, D. W. (2000. 'Global Climate Change in Agriculture'in Global Trade Analysis: Modeling and Applications. Thomas W. Hertel, editor,Cambridge University Press.

[29] UNFCCC (2003). Implementation of Article 4, Paragraphs 8 and 9, ofthe Convention Progress on the Implementation of Article 4, Paragraph8 Other Matters Report of the Workshop on Local Coping Strategiesand Technol. for Adaptation Note by the Secretariat.

[30]URT (2005). Singida Region Socio-economic Profile. Second eds,Printed with Cooperation of National Bureau of Statistics and SingidaRegional Commissioner"s office,

[31] Yanda PZ, Olson J, Moshy P (2008). Climate Change VulnerabilityImpacts and Adaptation in Tanzania. CLIP Working Paper. Inst. OfRes. Assessment, Univer. of Dares Salaam, Tanzania. 